Mitteilungen der Österreichischen Geographischen Gesellschaft,

156. Jg. (Jahresband), Wien 2014, S. 191-220

\title{
ISLAM AND THE HUNGARIANS
}

Norbert PAP, Péter RemÉNYI, Zsuzsa M. CsÁsZÁR, and Andor VÉGH, all Pécs*

with 4 Fig. in the text

\section{Contents}

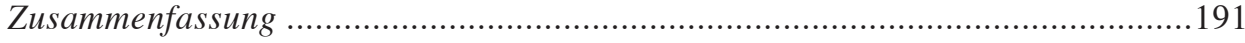

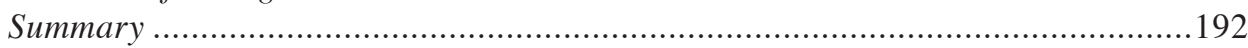

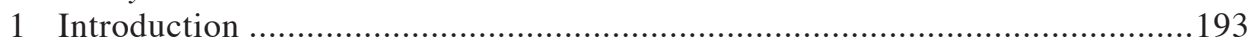

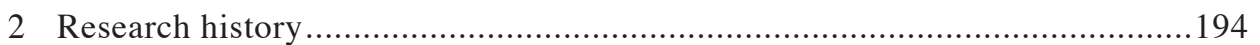

3 First contact with Muslim peoples .................................................. 195

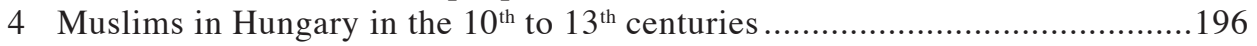

5 Muslims in Ottoman Hungary ......................................................... 198

6 Bosniaks and Turks in Austria-Hungary ...................................................201

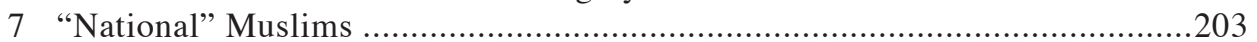

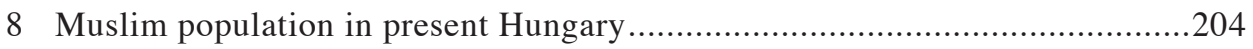

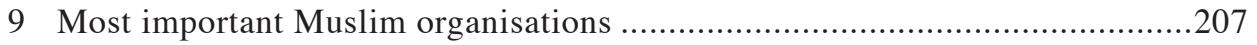

10 Institutions and practice in Muslim religious life....................................209

11 Social role and political importance of Hungarian Muslims .........................212

12 The role of Islam in Hungarian "national mythology" .................................214

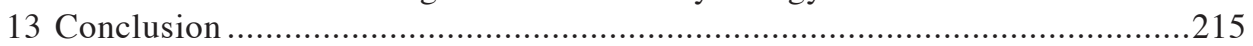

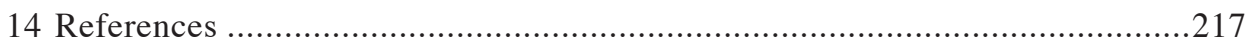

\section{Zusammenfassung}

Der Islam und die Ungarn

Der Artikel bietet einen Überblick über die fünf Perioden der ungarischen Geschichte, in denen Muslime Einfluss ausgeübt haben. Ethnischer Hintergrund, sozialer Status und räumliche Verteilung sind die Hauptpunkte, auf die er sich konzentriert. Im Mittelalter waren die Muslime asiatischer Herkunft, schlossen sich den ungarischen Stämmen an und wurden zu einer starken Stütze der Königsmacht als Finanzexperten

* Dr. Norbert PAP, Dr. Péter Reményi, Dr. Zsuzsa M. CsásZÁr, Dr. Andor VéGH, all Institute of Geography, University of Pécs, Ifjúság u. 6, H-7624 Pécs, Hungary; e-mail: pnorbert@gamma.ttk.pte.hu, remko@gamma.ttk.pte.hu, cszsuzsa@gamma.ttk.pte.hu, veghandor@gmail.com; http://foldrajz.ttk.pte. hu/munkatarsaink/vegh-andor-dr 
und Soldaten/königliche Garde. In der osmanischen Periode (1541-1699) wanderten zum Islam konvertierte südslawische und vlachische Gruppen aus Südosteuropa in die zentralen Gebiete des ungarischen Königreichs, die vom Osmanischen Reich besetzt worden waren. Sie dienten im Heer und spielten in der Verwaltung des Reichs eine fundamentale Rolle. Nach 1878, in der Zeit nach der Besetzung Bosniens und der Herzegowina durch die Österreichisch-Ungarische Monarchie, zogen Bosniaken und Türken nach Ungarn. Der rechtliche Status der islamischen Glaubensgemeinschaft wurde im Jahr 1916 festgeschrieben. Während des Ersten Weltkriegs und beim Aufstand gegen die Österreicher in den westlichen Grenzgebieten Ungarns (heute Burgenland) erwarben sich die Muslime durch ihre aktive Beteiligung große Verdienste. Dies begründete auch eine günstige Beziehung zu ungarischen Mitte-rechts gerichteten, revisionistischen und auch extrem rechten politischen Gruppen. Mit der kommunistischen Machtübernahme nach dem Zweiten Weltkrieg wurde den Aktivitäten der islamischen Gemeinschaft ein Ende gesetzt und viele Türken und Bosniaken verließen das Land. In den allerletzten Stunden des kommunistischen Regimes begannen Studenten aus arabischen Ländern und ungarische Muslime religiöse Organisationen einzurichten. Muslime aus ferneren Teilen der islamischen Welt ließen sich in Ungarn nieder, so vor allem aus arabischen Ländern, aber auch aus der Türkei, aus Zentral- und Südasien. Die räumliche Verteilung der Muslime in Ungarn hat sich seit ihrem ersten Eintreffen häufig verändert. Während des Mittelalters siedelten sie auf königlichen Gütern an verschiedenen Orten des ganzen Landes. In der osmanischen Zeit lebten sie in befestigten Siedlungen vor allem in den hügeligen und gebirgigen Gebieten. Später und heute konzentrieren sie sich auf die Hauptstadt und einige Regionalzentren.

\section{Summary}

The paper gives an overview about the five periods of the Hungarian history featured by significant Muslim influence. Ethnic background, social status and spatial distribution are the main points the study is focusing on. In the medieval period the Muslims were of Asiatic origin, joined the Magyar tribes and became a strong mainstay of the royal power as financial experts and soldiers/royal guards. In the Ottoman era (1541-1699) Islamised Southern Slavic and Vlach people from the Balkans migrated to the central parts of the Hungarian Kingdom occupied by the Ottomans. They gave military service and played a fundamental role in the administration of the Empire. After 1878, following the occupation of Bosnia and Hercegovina by the Austro-Hungarian Monarchy, Bosniaks and Turks migrated to Hungary. The legal status of the Muslim community was settled in 1916. During the First World War and in the uprising against the Austrians in the western border areas of Hungary (now Burgenland), the Muslims earned serious legitimacy by their active participation. This laid the cornerstones of a favourable relationship with Hungarian centre-right, revisionist, and also far-right political groups. When the Communists took power after the Second World War, activities of the Muslim community had been terminated, and many Turks and Bosniaks left the country. In the very last hours of the Communist era, 
students from Arabic countries and Hungarian Muslims began to establish religious organisations. Muslims settled in Hungary from farther areas of the Islamic world, including especially Arabic countries, and also Turkey, Central and Southern Asia. Spatial distribution of Muslims in Hungary has changed a lot since the first encounter. During the Middle Ages their communities settled in the royal estates in different places countrywide. In the Ottoman period they lived in fortified settlements mainly in the hilly or mountainous areas. In the modern period the Muslims are concentrated in the capital city and a few regional centers.

\section{Introduction}

With regard to the topic of Islamisation, Hungary has a history that is special and unique in Europe. A minority of the Magyar (Hungarian) tribes settling in the Carpathian Basin followed the Islam faith, which had been an element of the social basis of royal power, and therefore survived for centuries. After the assimilation in the Middle Ages, another significant Muslim immigration took place in the $16-17^{\text {th }}$ centuries, when the Ottoman Empire ruled over almost a third of the country. Some of the mosques constructed in the era still exist and are in use. After the liberation wars, a forced assimilation ended the Islamic presence. After another break, terminated by the occupation of Bosnia and Hercegovina by Austria-Hungary in 1878, some Muslim Bosniaks and (in smaller numbers) Turks settled in the region. After the First World War, a Muslim community formed in Budapest that had earned glory and legitimacy through their participation in the country's military defence. After the Communists took control, Muslim community life ended, only resuming in 1988, at the very end of Socialist rule. The current Muslim communities expanded at first through the waves of refugees from former Yugoslavia, and then as a result of increasing international migration. Nowadays, intensification of migration causes unexpected waves, which increases the number of Muslim believers coming from Kosovo, as well as from parts of Asia and Africa.

In the present paper the authors examine the different major periods of Islam presence in Hungary. With the help of the historical geographical perspective the authors intend to emphasise the long history of a common past as well as the degrees of significance that Islam played in these eras. Emphasis is given especially to the present time, due to its political and social importance and also to the sensitivity of the issue today. In their comparative analysis of different periods of Islam in Hungary the authors are seeking answers to the following questions: from which ethnic areas the followers of Islam arrived in Hungary; where they (were) settled; what social, economic and political roles they played in their own era; and how the majority population and certain subcultures related to them. With the help of the comparative approach, similarities and differences among the periods can be pointed out which may contribute to the wider understanding of Islam in Hungary and in Europe. 


\section{Research history}

Due to the eastern origins of the Hungarian people, and also to the significant impact of Ottoman rule on Hungarian history and the vividness of popular memories, efforts at orientalism have played a significant role in Hungarian scholarship since the $19^{\text {th }}$ century. Many researchers of early Hungarian history and the early Middle Ages, such as Antal BARTHA, György GyörfFY, Gyula Kristó, examined the issues of Muslims in the Carpathian Basin during their studies of the population mix of the conquering Magyars and the political relations at the time of Hungarian arrival in the area (BARTHA 1988; GYŐRFFY 1990; KRISTÓ 2003).

The Hungarian turkology school that was founded by Lajos FeKETE and Gyula KÁLDY-NAGY has achieved compelling results even to international standards in the research of $16^{\text {th }}$ - and $17^{\text {th }}$-century Ottoman history. The research conducted there forms the solid foundation for our knowledge of temporary Islam culture and institutions in the conquered territories, and the lifestyle of Muslims. Pál FodOR provided significant contributions to political dimensions, while Gábor ÁGOSTON acted similarly with regard to art history of the conquered lands (FodOR 1991; ÁGOSTON 1993; ÁGOSTON 2005). Klára HegYi uncovered the ethnic background and origins of the immigrant Muslims (Hegyi 1995). Balázs Sudár has performed significant studies in the fields of the cultural life of the conquered lands (music, literature) and the research of Sufi orders (SUDÁr 2003, 2008). The research group led by Norbert PAP has contributed to a better understanding of the urbanisation of the conquered territories and the religious life thereof, through their studies of the burial site and place of worship of Suleiman I near Szigetvár and the small town founded there (PAP 2014).

Scholarly publications on the current Muslim communities in Hungary and their properties have been appearing since the end of the 1980s. The first analytic, general articles written using a scientific approach were written by György LÉDERER (1988, 1989). Additionally, many young researchers published their first papers about the topic. Historian Zsolt UdVARVÖLGYI's remarkable thesis about the sociological features of the Hungarian Islamic Community [Magyar Iszlám Közösség, MIK], which has frequently been quoted, was a pioneering work, and he also published a paper on the establishment of the MIK (UDVARVÖLGYI 1998, 2010). Enikő KISS wrote her essay about the life of a Muslim community in Budapest using a general approach (KISS 2002).

The papers written by Hungarian Muslim religious leaders are also interesting contributions to the range of scientific publications (MıHÁlfFy 1991; BoleK 2002; Sulok 2010). The authors Zsuzsa M. CsászÁr and József Pete studied the issue in a wider, "Carpatho-Balkan" framework in their general, representative paper written through the eyes of geography scholars. Their work included an extensive overview of the scientific literature and the available statistics (CSÁszÁr \& PeTE 2008).

The number of specialised articles drafted with a scientific approach is low. The papers of László Csicsmann and Erzsébet N. Rózsa, based on interviews conducted 
with leaders of the Muslim communities in Hungary and the related NGOs, have recently been published, and these mainly discussed issues of community and political activities (Rózsa 2010; Csicsmann 2011; Csicsmann \& VéKony 2011). Norbert PaP (with co-authors in certain cases) for the most part published general reviews of the complete Muslim population in Hungary for the Yearbook of Muslims in Europe, based on the required criteria, in 2011, 2012 and 2013 (PAP 2011; PAP \& LADÁNYI 2012, 2013). He researched the operation of Muslim non-governmental organisations in a Central European framework for the periodical Civil Szemle (Civil Review), the migration and IT-usage of Muslims for the periodical "Information Society" [Információs Társadalom] with co-authors, and published his paper on the Sunni Muslim Community of Pécs in the periodical "Minority Research" [Kisebbségkutatás], which all serve as the basis for this publication (PAP 2013a, 2013b; PAp et al. 2013).

\section{First contact with Muslim peoples}

The early Magyar tribes made their first contact with Islam in the territory of the Khazar Empire (BARTHA 1988). We have very little irrefutable evidence about the times of our ancestors in the steppes, historical sources tending not to mention them till the early $9^{\text {th }}$ century. However, while nobody disputes the relationship with the Khazar Empire, there is a wide array of theories concerning the form and duration of this relationship. Between the $7^{\text {th }}$ century and the middle of the $9^{\text {th }}$ century, the Hungarians are most likely to have been subjects, made up from peoples of the multiethnic Khazar Empire, at the northern coastal regions of the Caspian and the Black Sea, where they slowly, but continuously wandered in western-southwestern direction. In the Khazar Empire, Islam spread after the Second Arab-Khazar War (approximately 722-737); contemporary sources report of broad Muslim social groups with their own mosques and judges (BARTHA 1968; FODOR 1988; GYÖRFFY 1990). It is also understood that Khwarezmians had lived in the Khazar Empire since the $8^{\text {th }}$ century. They were a Muslim people speaking an Iranian language, who held important positions in the military and the guards (AL-MASUdi quoted in GYÖRFFY 1990).

As the Hungarians split away from the Khazar Empire (the exact date is not known, but in approximately 850, FODOR 1988), they were joined by groups opposing the ruling elite, who in Hungarian historiography were called Kabars. One of the possible explanations for the schism is a Khazar civil war that took place simultaneously with the political elite adopting Judaism. The Kabars - organised into three tribes by the Hungarians - are likely to have consisted of many ethnicities (Alans, Khwarezmians, Volga Bulgars, Khazars) and religious groups (including Muslims). According to GYÖRFFY it was the Khwarezmian group (of Iranian origin) that formed the most significant group, and their decision to join the Hungarians - according to this theory was influenced by the Khazar elite's turning to Judaism (FoDOR 1988; GYörFFY 1990). 


\section{Muslims in Hungary in the $10^{\text {th }}$ to $13^{\text {th }}$ centuries}

It is no longer disputed that there were groups following the Islamic faith living among the ranks of the Hungarians in the Carpathian Basin. Historians seem to agree that the groups referred to as Khwarezmian in the sources followed the Muslim faith, and consisted presumably of the descendants of the Iranian residents of Khwarezm (Horezm), a town located at the southern coast of the Aral Sea (GYöRFFy 1990). They played a major role in the state between the dates of the Hungarian conquest of the Carpathian Basin and the establishment of the Hungarian state, and also in the early period of the Árpád dynasty. A part of them formed the armed escort of the ruler, played major roles in the royal army and in guarding the southern borders, while another part managed state finances (mintage, collection of taxes, duties), and so two state areas of major importance (running the military and state finances) were held (at least partially) by Muslims (GyörfFy 1990; Al-Garnáti [al-Gharnati] 1985). Consequently, they did not settle in one block as a nation/tribe, but scattered around the royal territories as required by their jobs/positions (see Fig. 1). There are traces of conflicts recorded in sources from the Middle Ages, between the Khwarezmian managers of royal revenues and the new possessors (the Christian Church), for example in the vicinity of the city of Nitra (GYŐRFFY 1990). Due to their roles in the operation of the government, they were for a long time important supporters of the ruler ${ }^{1)}$, and therefore they posed more than a mere "problem to be solved" for the Church with its increasing influence, for reasons of religious difference.

In the works of Abu Hayyan AL-GHARnATI, in addition to the Khwarezmians another Muslim group (Maghrebians) is also referenced, which lived in large numbers in the territory of Syrmia [Srem, Hungar. Szerémség] in the middle of the $12^{\text {th }}$ century. Their members also served the king, but unlike the Khwarezmians, they only provided military services and openly practised their Muslim faith. (According to Abu Hayyan AL-GHARNATI, in this era the Khwarezmians were secretive about their faith.) According to the traveller, the Khwarezmians and Maghrebians also lived in countless large numbers, and they preached in more than 10,000 places around the country every Friday. Many sources concurrently report on the presence of the Khwarezmians (although certain elements are dubious as regards their origins), but a lot of different theories exist about the Maghrebians (also mentioned under different names in Greek sources, in the writings of KinNAmOS) that try to answer the questions of the origins of this group (KATONA-Kiss 2010). They are sometimes considered to be Pechenegs and Alans, joining the Kabars at the Hungarian conquest of the Carpathian Basin (GYÖRFFY 1990), Oguzes (KRISTó 2003) as well as Seljuq Turks repatriated by the Byzantine emperors (KATONA-KISs 2010). According to certain sources, some of their groups were repatriated by the Byzantine ruler to his Empire around 1165, but there are also continuous reports on Muslim soldiers serving in the Hungarian royal army till the end of the $13^{\text {th }}$ century (GYÖRFFY 1990; KATONA-KISS 2010).

\footnotetext{
1) This is supported by the notion that apparently the anti-Islamic laws of Kings Ladislaus I and Coloman were not widely applied, because in such a case the Golden Bull of 1222 would not have had to repeat such provisions.
} 


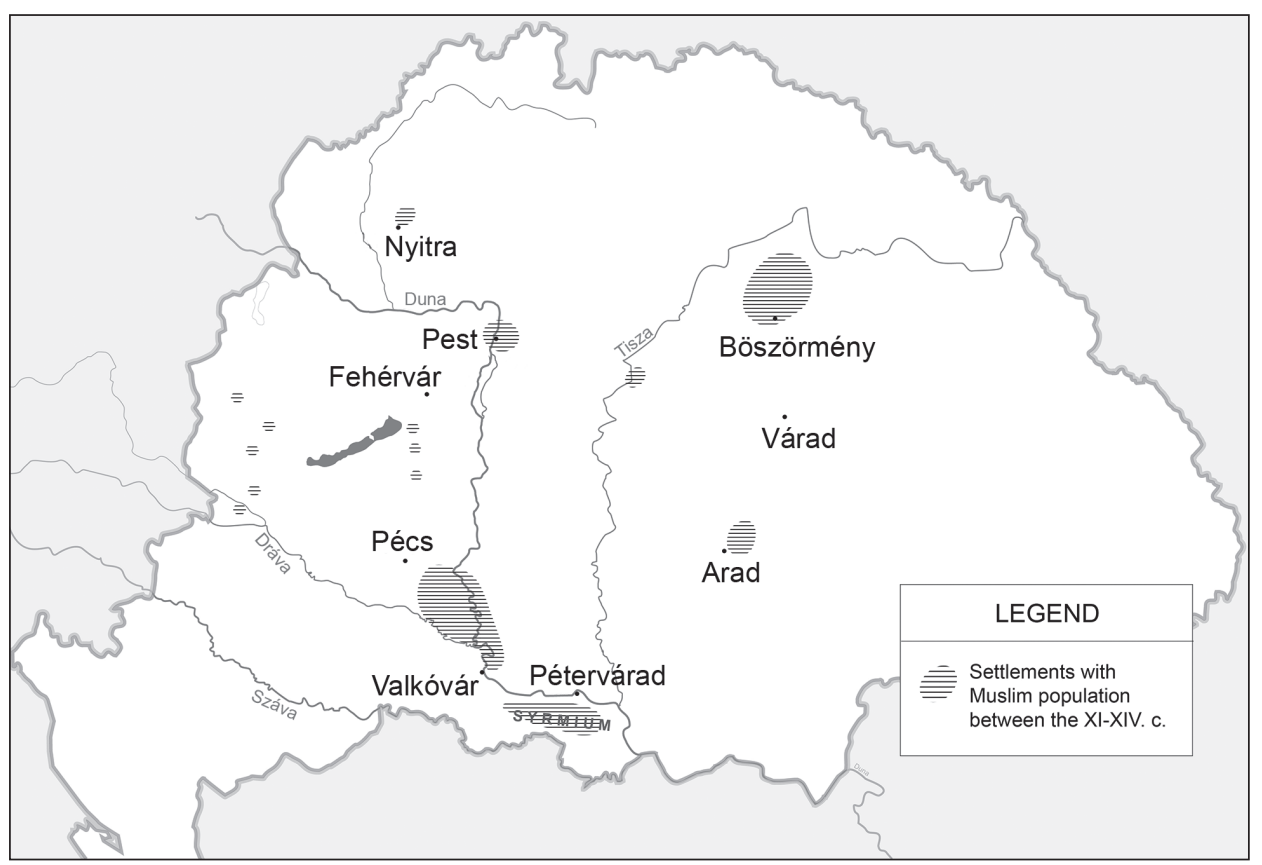

Fig. 1: Muslims in Hungary in the Middle Ages $\left(10^{\text {th }}-13^{\text {th }}\right.$ century $)$

In addition to those mentioned above, sources also report on other groups practising the Islamic faith. We know of Saracens arriving from Volga Bulgaria who settled around Pest and were therefore mentioned in a document issued in 1213; these are the "Böszörmény" people in the Nyírség region, who are also mentioned in royal charters in 1219 and 1222 (GYÖRFFY 1990). There are many theories (not detailed here) on the ethnic identity of the Muslims called Ishmaelites, Saracens and the "Böszörmény" people (KARÁCSONYI 1913), since the abovementioned terms basically only refer to their faith and they are often used interchangeably.

It is clear from the laws of Kings Ladislaus I (1092) and Coloman (around 1100), from foreign sources (AL-GHARNATI in the mid-12 $2^{\text {th }}$ century, Yaqut AL-HAMAWI in the early $13^{\text {th }}$ century), the Golden Bulls $(1222,1231)$ and the Bereg Treaty (1233) that Islamic faith groups were continuously present in Hungary until the middle of the $13^{\text {th }}$ century, and held positions (armed escorts, finances, sometimes openly influential political positions, such as the Palatine of Ladislaus IV) that disturbed the Church (with increasing influence) and the aristocracy. Primarily due to pressure from the Church, severely repressive measures were introduced in the early $13^{\text {th }}$ century to hasten their assimilation with Hungarians, but the issues of Ishmaelites and Saracens were still brought up at the Synod of Buda in 1279. Increasing attempts at assimilation had met with success by the end of the $13^{\text {th }}$ century, as the charter of the Synod of Buda and a mention of the palatine of Ladislaus IV in 1290 are the last written traces of Hungarian Muslims, while foreign sources report on the issue for the last time in 1224 (Yaqut AL-HAMAWI) (KRISTó 2003). 
Certain authors also consider the Pechenegs (preserving their identity) and the Cumans to be in part Muslim (ADORJÁn 1988: which would mean a larger spatial extent of Hungarian Islam in the Middle Ages and also a longer such period, presumably till the Anjou era in the $14^{\text {th }}$ century) but representatives of mainstream history disagree (PÁlócZi-Horváth 1988).

\section{Muslims in Ottoman Hungary}

Followers of Islam reappeared en masse in the Carpathian Basin in the $16^{\text {th }}$ century. A part of the territory of historic Hungary belonged to the Ottoman Empire from 1541 to 1699 (1718) and large Muslim populations started to appear in this region. The gradually extending central third of the country (with Buda as its centre) became part of the Muslim World (the "House of Islam") till the end of the $17^{\text {th }}$ century, and the authority of the Sultan was directly applied. In the eastern part of the Carpathian Basin, the Principality of Transylvania [Ardeal, Hungar. Erdély] preserved its independence as a vassal state. A similar vassal state existed for a short period of time in the northern part of Upper Hungary (in the territory of contemporary Slovakia), under Prince Imre Thököly (1682-1685). However, Muslims did not settle in these two states. Liberation wars commenced from 1686 and the larger part of the occupied territories was liberated in 1699, while the Banat became free in 1718 and re-entered Christian European structures.

Contrary to certain areas of the Ottoman Empire in the Balkans, the Ottoman authority in Hungary remained temporary from a certain aspect, meaning that Islam could gain significant presence, and Muslim communities did appear in the network of settlements of the occupied territories (FODOR 1991). During the beginning of the Turkish conquest, the population of the Kingdom of Hungary was 3.5 million, while approximately 900,000 people living in the area conquered by the Ottomans in the $17^{\text {th }}$ century $\left(120,000 \mathrm{~km}^{2}\right)$, including presumably 50,000-100,000 Muslims $(50,000-$ 80,000 according to different sources) taking into account also the soldiers serving in the area. Mainly from the research of Klára HEGYI, it is today well understood that the majority of soldiers serving in the Turkish border fortress system were Islamised men from the Balkans. They came to the occupied territory mainly from Bosnia, Serbia, the region between the Drava and the Sava rivers and Hercegovina. The number of ethnic Turks was rather low, only a few settlements being known to have had a significant proportion of such residents (including the towns of Esztergom, Szentes, and Tolna). The number of Hungarian converts was very low, and official politics did not support mass Islamisation either, converts were rather exceptional. Bosnian properties dominated in the Muslim society of Hungary, and due to the Sokollu family belonging to the political elite of the Empire, there existed a lively political connection with the Bosnian territories. The social structure of the Muslim society was similar to those developed in various regions of the Balkans, just as the structure of Hungarian society was also identical with that in the Balkans. 
In Hungary, Muslims settled in border fortresses and the more important, protected settlements, without establishing any major independent townships ${ }^{2)}$ (with only one exception) (see Fig. 2). The most important cities - Buda, Pécs, Temesvár [Timişoara] and Szeged - became regional centres in the Kingdom of Hungary, and they also preserved their status in the Ottoman Empire. Market towns on the Great Hungarian Plain [Alföld] (without defence capabilities) were khas properties, and as such they paid significant contributions to the treasury, for which they enjoyed wide autonomy and no Muslims moved within their boundaries. The cities gained an oriental character. The street grid from the Middle Ages did not change, but the local administration organised parts of the settlements in districts (mahalle) according to the Ottoman model, with certain religious structures at the centre. ${ }^{3)}$ The original residents were often removed

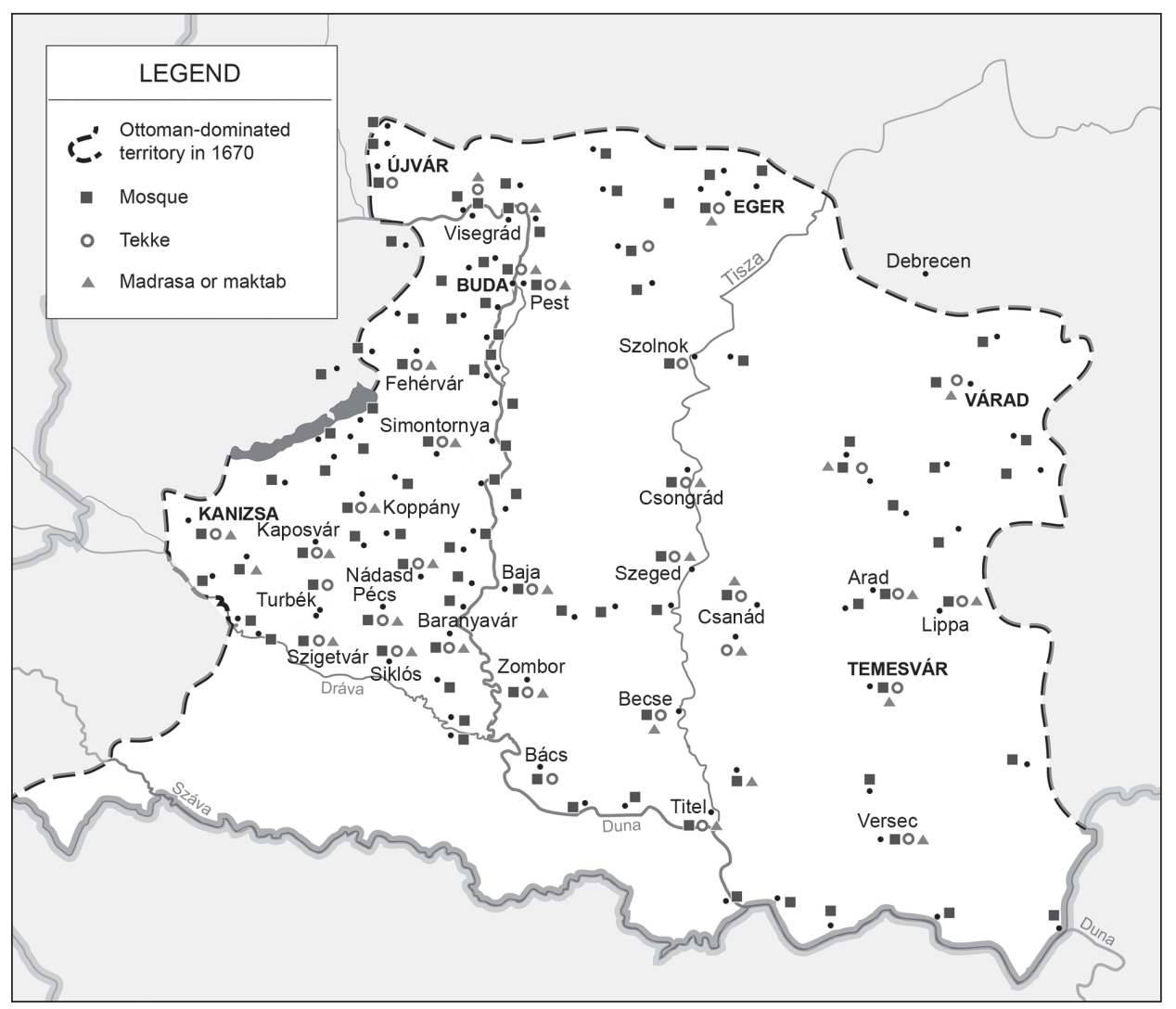

Fig. 2: Settlements in the occupied area of Hungary with Muslim populations $\left(16^{\text {th }}-\right.$ $17^{\text {th }}$ century) (based on SudÁr 2003)

2) The small town referred to as Turbék was established near Szigetvár, and it developed around the tomb of Suleiman I for funerary, religious and political considerations (PAP 2014).

3) In the cities, places of worship (mosque, cami), Dervish monasteries (tekke or derga), soup kitchens (imaret) public baths (ilija, hamam) and schools were established. Fountains (cheshme), craftsman workshops and the stores of traders appeared in the main streets. 
from the city boundaries, and resettled outside the city walls or to nearby villages, while Christian churches were transformed into mosques.

The invaders established the municipal frameworks of their Ottoman-like lifestyles. The castles and palisades only had a mosque or cami servicing the small number of guards and no other religious/cultural institutions. According to SUDÁr, in the $17^{\text {th }}$ century civil residents and the fragmented system of institutions were concentrated in 30-35 cities of the occupied territories (SUdÁr 2003). According to Evliya ÇElEBI, 165 mektebs (elementary level religious schools) and 77 medreses (or "madrasa", secondary and higher level theological school), servicing Muslims, operated in these townships (EvLIYA ÇSELEBI 1908). The numbers are probably not accurate - as is often the case with $17^{\text {th }}$-century travel literature -, but they give a good insight into the magnitude of the situation. Islamic mysticism flourished, and the Bektashi, Khalwati and Mevlevi Dervish orders established their monasteries. The city of Pécs especially became a centre of Sufism. The tomb of Suleiman the Magnificient in Turbék (near Szigetvár) became a major destination of pilgrimage (ÁGOSTON 1993). The tombs of Gül Baba in Budapest and Idris Baba in Pécs were also spiritual centres.

The era of Ottoman occupation was terminated by the liberation wars (1686-1699). The civilian Muslim residents usually fled along with the retreating Ottoman armies. Practically no Muslims remained in the recaptured territories. Those that did not flee usually converted to Christianity in order to save both their lives and their properties. The number of Muslims converting to Christianity is estimated to be a few thousand. Many Slavic groups from the Dinarides region also participated in the mass immigration to the area after the liberation wars. They include groups originally from the Balkans, who had converted to Christianity and mixed with these peoples, yet sometimes preserved their names (Hadžija, Kadija, Karagić, Alagić, etc.) and occasionally their Bosniak identity as well ( $\left.\breve{S}_{\text {AROŠAC }} 1991\right)$. Originally Muslim, by the $17^{\text {th }}$ century they had Catholicised and later became parts of the Croatian nation, primarily due to their Catholic faith. Current populations with such roots include the Bunjevci in Bácska (also in Serbian Bačka), and especially the Bosniaks and Croats living around Pécs and Szigetvár (Kitanics 2006; SoKCSEvits 2011).

Towns in the formerly occupied areas regained their Western-style features and the Muslim religious institutions and estates were transferred to the Catholic Church. Camis, mosques and tombs were typically transformed into Christian places of worship or sometime used as warehouses. Other mosques, originally Christian churches, underwent a new transition back into a Christian building.

The era of the Ottoman occupation entered historical memory with very negative attributes. It was also often cited as an original cause for the deterioration and decay in the later eras (such as the detrimental consequences of the Treaty of Trianon on the population and the territory of the country after the First World War). However, relations with the Turks and the Ottoman Empire in fact gradually improved, since freedom fighters against the rule of the Habsburgs often sought asylum in Turkish lands after their attempts failed (Thököly, Rákóczi, Kossuth). 


\section{Bosniaks and Turks in Austria-Hungary}

A new era of Islam in Hungary began when Austria-Hungary occupied BosniaHercegovina in 1878. A slow influx of Muslim residents from Bosnia began in the direction of Hungary, mainly made up of Bosniaks and Albanians, but also people of Turkish origin. The former Hungarian finance minister ${ }^{4)}$ Béni Kállay was in charge of governing Bosnia and Hercegovina from 1882, and his policies favoured the integration of Muslims, thus accelerating the immigration of Muslims to Hungary. The first step in their emancipation was Article I of Act XLIII of 1895. This introduced religious tolerance for Muslim Bosniaks already living in the area or arriving after the occupation. Nevertheless, according to the data of the 1910 census, only 757 Muslims were living in Hungary, and only 553 not including the territory of Croatia-Slavonia. Of these, 319 were Bosniaks and 179 Turks, most of the former being soldiers. The number of Muslims increased in 1913, when the island of Ada-Kaleh (Hungar. Új Orsova, also Nova Orsova) with approximately 500 Turkish residents, which had been occupied in 1878, was formally annexed by Hungary (LEDERER 1988). An important remark: According to the census of 1910, 612,137 Muslims lived in Bosnia-Hercegovina. According to FERENCI, the first group of Turks (most of them were craftsmen, confectioners, students) arrived in Hungary in 1909, together with their religious leader Abdul Latif ${ }^{5)}$ (FERENCI 2010).

With regard to Muslims in Hungary, Turkish connections are not only apparent in the alliance with the Turks during the First World War. There were many displays of mutual sympathy from the 1870s onwards. In the Russian-Turkish War the Hungarian public supported the Turks and street demonstrations were organised to show this support. In 1877, a delegation of Hungarian university students paid an honorary visit to Istanbul [İstanbul], and presented a ceremonial sword to the victors of the Battle of Pleven. The Turkish party organised a follow-up visit to Hungary the following year (FERENCI 2010).

\footnotetext{
4) The Austro-Hungarian ministry of finance was held by Hungarians, and governance of occupied BosniaHercegovina was attached to this position. Béni Kállay held this office from 1882 to 1903 and made enormous efforts to strengthen the identity of the Bosniak people, and to develop the rule of law and the economy of the territory. It was in the interest of the contemporary political elite to develop a separate Bosnian Muslim identity instead of a joint Southern Slavic unity. The development of a Bosnian Muslim identity was a conscious policy.

5) Abdul Latif, in Turkish Abdüllatif, or in Turkish sources Erzurumlu Abdüllatif Tanrisever, was born in the town of Erzurum in the Ottoman Empire in 1886 (Duman 2010). His birth certificate and school diploma from the Fatih Madrasa was issued in Ottoman Turkish writing, and presumably his passport as well, which he used to travel to Hungary in March 1909, after travelling through Bulgaria and Bosnia. According to contemporary sources, the Hungarian Muslims requested a hodja, a religious teacher from the Turkish Empire. He was an educated man who completed two years at the University of Istanbul [İstanbul] (ex verbis FERENCi 2014). He was also an honorary member of Turáni Társaság, with Ahmet Hikmet, Ahmed Zeki Velidi, Behiç Erkin, Hamdullah Suphi Tanrı̈ver (DÁvid \& OLÁH 2012). He was also active as a Turkish interpreter and language editor and some sources also record him as being a university lecturer. His then residence is also known: Budapest, Krisztina krt. 159., Floor I, Door 1. (HOM. Múv.tört. Adattára). He died in 1946 and was buried in the graveyard for Muslims in the Rákoskeresztúri Újtemető cemetery, Budapest, near the grave of Durics Hilmi Husszein.
} 
The Hungarian Turan Society [Turáni Társaság] ${ }^{6)}$ played an important role in strengthening ties during the war, by actively participating in economic, cultural and political cooperations. The Hungarian Oriental Cultural Centre [Magyar Keleti Kulturális Központ, MKKK] - founded in 1916 - should also be mentioned, as it had close relations with Turkey and Bulgaria. One of the benefits of the MKKK and the Hungarian Turan Society was that it invited 200 Turkish, and some other Bulgarian, Bosnian and Albanian Muslims to Hungary as students. According to sources, from 1916 to 1924 100-150 Turkish, 30-40 Bosnian and 21 Albanian students arrived, all of whom were regularly visited by the Turkish imam Abdul Latif (FARKAS 2007).

In the early 1910s several smaller Muslim groups were known in Hungary. A significant number of Bosnian Muslims entered the army. For these reasons, the need for legislation on the status of the Muslim faith was an important issue in 1913, especially as this had already been concluded in Austria in 1912 (Act 159/1912). Finally, the Hungarian parliament declared Islam a recognised religion in Act XVII of 1916. According to the justification of the act, the "principles and doctrines of Islam are not compatible with our current laws, due to historical developments differing from those of our country", and therefore the recognition required a higher level of regulation, in the form of an act of parliament.

In 1916 the acclaimed Hungarian geographer Rezső Havass, a member of parliament, suggested that the capital city, Budapest, should build a "house of worship" for Muslims, and the Council of Budapest accordingly adopted a resolution on April $4^{\text {th }}$. With chairman Zsigmond Perényi, the Council established a Mosque Construction Committee, although eventually they failed to construct a Muslim house of worship over the following years. In the same year, Múzeum körút (a section of the Budapest Small Boulevard) was renamed "Mehmed körút". According to some researchers (LÉDERER 1988; ANWAR 2001), in 1916 approximately 2,000 Muslims lived in Budapest. According to LÉDERER, most of them were Bosnian soldiers, Albanian craftsmen, workers and students, but there were also some Turks. It is worth noting that many identified the Muslim residents of the country simply with Turks, and considered Islam a Turkish faith. Many think that the Turkish envoy to Hungary, Abdul Latif played a great role in spreading these notions (FERENCI 2010).

The presence of Bosnians from the era of the Dual Monarchy also added an interesting class of itinerant merchants to the range of Hungarian Muslims. The travelling salesmen called Bosniaks, Aliyahs or Ilyahs appeared immediately after the occupation of Bosnia and there are records of them until the 1930s. These traders typically wore a fez, baggy trousers and leather vests, carrying baskets or wooden boxes hanging from their neck, and they reached almost all areas of Hungary, especially the regions of Transdanubia [Dunántúl] (according to the data from later years) (ORTUTAY 1977; PALÁdi-KovÁcs 2000).

\footnotetext{
6) It was founded in 1910 . One of the founders was Pál Teleki, the greatest Hungarian geographer of the $20^{\text {th }}$ century, who later became prime minister on two occasions. The objective of the Society was to combine oriental research with economic expansion, with the target areas of Asia Minor and Central Asia. This objective is in alignment with contemporary political goals.
} 


\section{7 “National” Muslims}

After the collapse of Austria-Hungary, many Bosnian soldiers and civilians remained in post-Trianon Hungary. Among them, the most famous and acclaimed person was the Muslim religious leader Durics Hilmi Husszein ${ }^{7)}$, who moved to Hungary from Vienna [Wien] in 1920, where - according to his own report - he joined Pál Prónay's paramilitary unit, the so-called "Rongyos Gárda" (Ragged Guards). ${ }^{8)}$ In their resurrection in the Banat of Leitha [Lajtabánság] region of Western Hungary of 1921, Bosniak, Albanian and Turkish Muslim volunteers are known to have participated. The Turkish, Bosnian and Albanian fighters are mentioned in several contemporary sources as well as the memoirs of one of the commanders of the troops. ${ }^{9)}$ Their units are well known as are the names, places of birth, ranks and civil occupations of some of them. The Muslim insurgents mentioned in the sources are the following: Pazarecs Hazson, candy trader, born in 1890, Ómere Dendics, platoon leader, Muhara Gondze and Gavrila Csabuk, Husszein Ibrahim Hilmi Turkish miner, Ahmed the Bosniak, machine gun operator, Tirnadzics Ibrahim, volunteer, born in Sarajevo, Tabakovics Hazsin, volunteer, born in Sarajevo, Zsikó Ahmed, volunteer, born in Sarajevo, Ali Fasil, commander of the Bosniaks, and Hasszán commander of the Albanians. Some of them were traders operating near the Western Railway Station [Nyugati pályaudvar] of Budapest, some others were defecting soldiers originally from southern Hungary. There are currently no exact data available on their numbers, but based on the different sources their numbers are estimated to be between 100 and 150 . In the case of the Albanians, the religious distribution (share of Muslims and Christians) cannot be verified. Commanders reported on the high military value of Muslim fighters, who proved to be tactical and courageous soldiers against the Austrians, fighting especially efficiently in the hills around the town of Sopron.

\footnotetext{
7) Durics Hilmi Husszein was born in 11 November 1887 in the town of Bosanska Krupa, where his father was a local magistrate. He completed secondary school (Darul Muallimin) there and allegedly earned his higher level Muslim theology degrees in Cairo [Al Kahira] and Constantinople [İstanbul]. In addition to Hungarian and Bosniak languages, he also spoke German, Turkish, Arabic and Persian. At the beginning of the First World War he was drafted for military service, and served in a Bosniak unit as a military imam. In October 1920 he moved from Vienna [Wien] to Budapest, and a year later joined Prónay's paramilitary unit. He was awarded Hungarian citizenship in February 1927, and was the leading founder of the first modern era Muslim community in Hungary on 2 August 1931 . He died in 1940 at the age of 52 of a pulmonary disease (published in BOLEK 2002).

8) Armed resistance was organised because the Treaty of Saint-Germain in 1919 awarded a western line of the Hungarian counties Moson, Sopron and Vas to Austria, covering a total area of 4,000 square kilometres and 50,000 Hungarian residents. Some of those who could not accept the decision, organised armed resistance and insurrection, with Pál Prónay and Gyula Gömbös being the leaders of the movement. The former - with approximately 120 insurgents recruited with Iván Héjjas - attacked an Austrian unit of 500 gendarmes awaiting the take-over of Sopron near Ágfalva on 29 August 1921. The insurgents were called Ragged Guards [Rongyos Gárda] as they operated without official recognition from the Hungarian government. The number of insurgents was between 3,500-4,000 and they held the front line of more than $200 \mathrm{~km}$ for four months (TARJÁN 2014).

9) Viktor Maderspach, a commander of the insurgents, mentioned them. His memoirs are published in issues of the Magyarság daily newspaper from 1926, and some parts are included in the paper of László Fogarassy, published in the Sopron Review [Soproni Szemle] in 1978.
} 
Later on, this turned out to be a very significant event, and the bloodshed and the efforts in Hungarian interests provided certain prestige and legitimacy for the Muslim community in Hungary during the interwar period.

In the 1920s the number of Muslims living in Hungary decreased by a third, to only 291 persons according to the 1930 census (FAZEKAS 1996). According to LÉDERER however, in the interwar period about 300 Turkish and 700-800 Bosnian Muslims lived in Budapest (LÉDERER 1989). Although the sources differ, we can be sure that Muslims concentrated in Budapest in the 1920s and 1930s, where Durics Hilmi Husszein led the Bosnian Hungarian, and Abdul Latif lead the Turkish community, often in rivalry with each other. Durics joined the political party National Front [Nemzeti Front] and was on good terms with prime minister Gyula Gömbös and far-right groups. During his public appearances he courted revisionist groups.

In 1931, under the leadership of Durics, the Budapest Autonomous Islamic Religious Community was founded, named after Gül Baba. The community utilised an international campaign to collect enough funding for establishing a mosque and a Muslim centre near the tomb of Gül Baba in Budapest. These efforts did not materialise in the end. Durics died in 1940 and Hungary was caught up in the Second World War on the losing side.

With the rise of Communism, the opportunities to practice the Muslim faith became rather limited and official politics were hostile. Some Muslims fled the country, and only a few are known to have stayed. The last of the Bosniaks of Durics, a man named Abid Csátics (Bolek 2002) died in a retirement home in Budapest. It is a strange coincidence that Gyula Germanus ${ }^{10)}$, the world-famous Muslim, orientalist and popular writer that presented the Islamic world to Hungary, was to become a member of parliament in the Communist, one-party era.

During the Communist era it was impossible to maintain the previously established relationships with Muslim states. Turkey became a member of NATO, the Bosnian Muslim territories were situated within Yugoslavia that was considered hostile at first, and non-aligned throughout. International passenger traffic was very strictly limited. International relations with "friendly" Socialist countries having a Muslim background were based on the then official ideology of atheism, and migrants only arrived in very small numbers for the purpose of study or work.

\section{Muslim population in present Hungary}

The origins of the contemporary Muslim community in Hungary date back to the second half of the $1980 \mathrm{~s}$, the last days of the Communist regime. The first Muslim communities, organisations and places of worship were established in university cit-

\footnotetext{
10) Gyula Germanus (1884-1979), the most famous Hungarian Muslim, scientist, writer, socialite, and for a period member of parliament (1958-1966).
} 
ies by Hungarian converts and Muslim students from Arab countries (BOLEK 2002, UdvarvölgYi 2010; Sulok 2010). Their numerical gain began with the transition to democracy in 1989/90, when the administrative constraints of travel and resettlement in Hungary eased and the country began to converge with Western and European structures.

Nowadays, the municipalities with Muslim populations are typically cities, primarily Budapest and its urban agglomeration. They rarely appear in rural areas. However, there are also cases where Muslim doctors are working in villages. The most important locations include Budapest, Miskolc, Pécs, Szeged, and Debrecen. There are certain divisions within the Muslim community, whose main groups include Sunnis and Shias; Arabs, Turks and other non-Arabs; immigrants and ethnic Hungarians.

\subsection{Migrants from different areas of the Islamic world}

Migrants arriving from distant areas play the most significant roles in contemporary Hungarian Muslim communities. In the 2010 survey 32,618 Muslims were registered, 17,925 of whom were Arabs, 3,350 were students (Arab and non-Arab), the number of non-Arab Muslims being 11,343, including Hungarian converts $(2,523)$ and migrants from the Balkans (Bosnians and Albanians, classified below), who also numbered several thousands (SULOK 2010). Today, an overwhelming majority of migrants arrive through migration routes via the Balkans, travelling through Turkey, Greece, Macedonia and Serbia and entering Hungary through the border near Subotica (Hungar. Szabadka) (PAP et al. 2013). In the last few years, about 2,000 asylum-seekers have been registered annually. In 2013 a larger wave of migrants $(18,895)$ reached Hungary, including an increasing number of asylum-seekers from Pakistan, Afghanistan and Kosovo. ${ }^{11)}$

\subsection{Refugees of the Yugoslav Wars, Bosnian and Albanian immigration in Hungary}

It will be worthwhile considering the role of Muslim territories in the Balkans, which used to play a major role in Hungarian Islamisation. During the course of the wars after the dissolution of Yugoslavia (the Bosnian War of 1992-95 being the most significant from our point of view) thousands of refugees found asylum in Hungary. This war period created several waves of Muslims appearing as refugees and being located to refugee camps. It could also be observed, however, that Bosniaks did not only move to refugee camps, but also tried to solve their housing individually in significant numbers, thus increasing the prices of available real properties near the eastern part of the Hungarian-Croatian border (VÉGH 2004). In the spa town of Harkány for example, they appeared en masse as tenants in the houses typically only used in the high season (GYUROK 1994). For this reason the official number of Bosniak refugees should be reviewed, as officially it was as follows: Békéscsaba 100 persons, Bicske 11) According to official data of the Office of Immigration and Nationality, in 201318,895 refugees sought
asylum in Hungary. This group included 6,210 Kosovars, 3,080 Pakistanis and 2,330 Afghan citizens. 
130 persons, Nagyatád 100 persons, Vése 180 persons, Erőspuszta 20 persons, Nagyharsány 30 persons (GyuroK 1994). The last Bosnian refugees to leave for Hungary in an organised manner left in 2002. Many of them became Hungarian citizens and established their families in the country, and therefore did not return to their pre-war homes in Bosnia, but have kept practising their religion as members of the Hungarian Muslim community.

In the early 2000 s, only partially due to the commencement of the military crisis in Kosovo, an increasingly significant number of migrants specialising in the bakery trade appeared in Hungary, especially from the territories of Kosovo and Macedonia (with only very few of them actually coming from Albania). This process intensified around 2008-2009. Of the approximately 1,600 bakeries operating in Hungary, about 400 have Albanian ownership (according to the data of the Bakery Association). The exponentially increasing Albanian presence in the bakery business is demonstrated by the following data: In 2011 143, in 2012 374, while in the first half of 2013 more than 266 Albanian bakers applied for an operation licence (although not all of them were granted one)! Since these migrants primarily arrive from areas where $90 \%$ of Albanians practice Islam, it is rational to presume that the entrepreneurs and workers settling in Hungary are typically not Orthodox or Catholic Albanians. This suddenly appearing and increasingly significant number of bakers (and a few confectioners) only cause social tensions due to dubious business practices (tax fraud, non-compliance with food industry standards, practice of irregularities in employment) and not because of their Muslim faith.

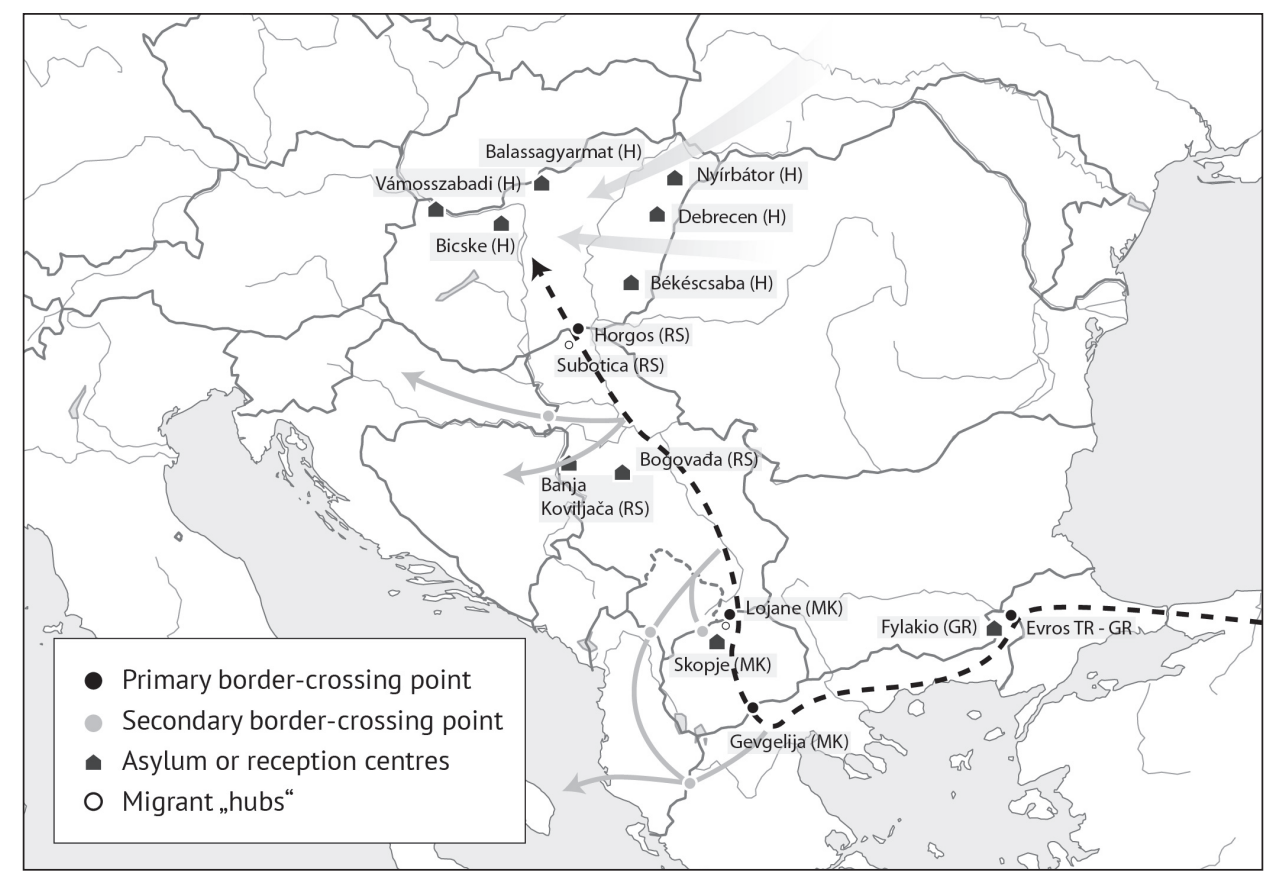

Fig. 3: The most typical route of illegal migration to Hungary through the Balkans 
It is safe to conclude that Islamisation from the Balkans has not played a major role in the reorganisation of Islam in Hungary, but is only of auxiliary importance. The main reasons for this include the more significant role of Austria and Germany as a migration target in the last decades, which has caused the attractiveness of Hungary to deteriorate (at least temporarily) among Bosnian Muslims. However, given the proximity of the territory of Bosnia and the traditional relationships between the two countries, Hungary could remain a factor in politics and religious policy.

\subsection{Hungarian Muslims, converts to Islam}

According to the publication of Zoltán Sulok, in 2010 there were 2,523 $(7.7 \%)$ ethnic Hungarians among the followers of Islam in Hungary. Other popular data cite larger numbers, such as estimates of 3,500 persons or 10\% of Muslims in Hungary (Csicsmann \& Vékony 2011). The data found in the Sulok publication appear to be normative. Compared to other European states, this proportion seems rather high. The number of converts in the Visegrad Group countries (Czechia, Hungary, Poland and Slovakia) is similar, estimated to be around $10 \%$, while according to the national reports in the Yearbook of Muslims in Europe this figure is typically much smaller (significantly smaller in certain cases) in Western Europe (NIELSEN 2013).

In the course of the questionnaire studies conducted in Pécs $(2010,2011)$ the sample included a significant number of converts (PAP 2013b). The majority of the converts - in a manner related to local religious traditions - changed their religions from the Catholic denomination, and there were also some Protestants. In accordance with the regularity of the practice of faith typical for the majority population, $68 \%$ of these did not regularly practice their religion. The majority of the questionnaires were answered by women. This partially supports the notion that Muslim communities are mostly being extended by the Hungarian wives of male Muslim immigrants who have settled in Hungary. However, several male converts are also known.

\section{Most important Muslim organisations}

\subsection{Church organisations}

The primary religious organisation with church-like attributes is the Hungarian Islamic Community [Magyar Iszlám Közösség, MIK], founded by Balázs Mihálffy in 1988 (UdVARVÖLGYI 1988, 2010). Its establishment was based upon legislation implemented in 1916. The leader (chairman) of the church is a Hungarian, Zoltán Bolek, and the majority of the members are also Hungarians. The community is characterised by strong nationalistic and patriotic commitment in addition to its religious character. Members partially embrace the Bosnian-Hungarian traditions of the interwar period. They also emphasise their connections with Bosnia-Hercegovina. They regularly organise charity events, maintain Muslim missions in refugee camps and provide prison chaplain services. 
Most recently, Muslim organisations have been organised pursuant to the new laws of the country transforming into a democracy. The status of Hungarian Islamic communities was regulated by acts on the freedom of conscience and religion (Act IV of 1990 and Act CCVI of 2011), non-governmental organisations (Act II of 1989 and Act CLXXV of 2011) and the legal status of refugees (Act LXXX of 2007). The permissive provisions of Act IV of 1990 on the freedom of conscience and religion and churches provided the opportunity for other Muslim organisations to be organised.

The Association of Islamic Students [Iszlám Diákok Egyesülete], was founded as a non-governmental organisation a year before MIK, in 1987. This association was partially a community and an organisational predecessor of the Organisation of Muslims in Hungary [Magyarországi Muszlimok Egyháza, MME], established in 2000. Its two branch centres are located in Szeged and Pécs, and the entity is a member of the international organisation, the Federation of Islamic Organisations in Europe. The leader of the organisation is a Hungarian, Zoltán Sulok, and members include a high proportion of non-Hungarian members.

The third organisation, Islamic Church [Iszlám Egyház], has the lowest number of members. It was founded in 2003 by a small number of believers who split from the MME and its centre is the Dar-as-Salam Mosque in Budapest. The religious leader is thought to be Tayseer Saleh, who follows the doctrines of Neo-Salafism and is of Palestinian origin.

Due to the situation caused by an amendment of law in 2011, the Muslim organisations were forced to cooperate and the two larger organisations (MIK and MME) established the Hungarian Islamic Council [Magyarországi Iszlám Tanács]. This (currently unregistered) organisation represents Hungarian Muslims pursuant to the law, but the two founding organisations are also considered legitimate representatives of Muslims. However, it is the common conclusion of our research and the studies conducted by CSICSMANn, that the three churches are only able to organise a minority proportion of believers, and a significant part of the Muslims asked answered that they do not consider the leaders of the three organisations to be legitimate (CSICSMAnN \& VÉKONY 2011; PAP 2013b).

\subsection{Muslim NGOs}

There are numerous Muslim organisations among non-governmental organisations (NGOs). The one with the longest history is the aforementioned Association of Islamic Students [Iszlám Diákok Egyesülete], founded in 1987 mostly by persons connected with the MME. The Dialogue Platform Association [Dialógus Platform Egyesület], which is related to the Gülenist movement, was established in 2005 and has Hungarian and Turkish members. ${ }^{12)}$ In addition to the translation of Gülenist principles and publication activities they also organise conferences. The Hungarian Islamic Cultural Association [Magyarországi Iszlám Kulturális Egyesület] was founded in 2008 by

${ }^{12)}$ Fethullah Gülen (1941-) is a Turkish religious scholar and leader living in the US. The Gülenist movement has major political influence in Turkey and it has gained very strong positions among the Turkish diaspora. 
Turkish and Hungarian private individuals. The organisation is related to the Suleiman movement of Sufi mysticism. ${ }^{13)}$ Their most important activity was to initiate the establishment of a cultural centre in Szigetvár Castle, with a budget of one billion forints, which attracted national media attention. The Aluakf Foundation [Aluakf Alapítvány] operates in Miskolc and maintains a prayer house there as well.

Muslim religious and non-governmental organisations partially face similar problems all over Europe, and therefore their reactions are similar also. The provision of a place of worship and the transfer of religious teachings (via events, translations, publications and language training) take a central position.

The overwhelming majority of Hungarian Muslims are Sunnis, but some Shia groups are also present in smaller numbers. The differences in ethnicity or religious matters have led to separate organisations. The groups with Turkish and Sufi background have separate organisations from the Sunni majority, and they have created units participating in international networks. Migrant, local Muslims and converts cooperate in various ways, and we have not discovered complete isolation during our inquiries.

\section{Institutions and practice in Muslim religious life}

\subsection{Mosques, prayer houses and prayer rooms}

In Hungary, permits are required for mosques and prayer houses to be established and to operate. There are dozens of such places available throughout the country. However, no sanctions are imposed on failing to fulfil formal requirements. Presumably, further prayer rooms operate in family homes and their numbers may significantly exceed the number mentioned above (see Fig. 4).

The establishment of "new" places of worship and prayer rooms must be reported, while newly built establishments require permits. Plans are inspected by the local construction authority and based on that a permit is issued or building permission withheld. The opinions of those living in the vicinity of the constructions are also considered. In Budapest, several prayer rooms are used as mosques which have been transformed from apartments, office buildings and warehouses, but these do not show the typical forms of camis and have not caused significant opposition from neighbours. No civil unrest or protests are known to have been caused by such establishments.

There are currently eight such known mosques in the capital. A classical type cami with a dome and a minaret has not yet been built in Hungary, and there is only one in the territory of historic Hungary, in a Hungarian town on the other side of the border, in Subotica Serbia. The most significant such building, the Budapest Mosque - which serves as the centre for the Church of Hungarian Muslims (MME) - is located on Fehérvári Road in Budapest, and is a former multi-storey office building. The establishment has a capacity of 2,000 people. In addition to its religious function it is also

\footnotetext{
13) Süleyman Hilmi Tunahan (1888-1959) is a Turkish religious scholar and Sufi master, who currently had about 4 million followers worldwide. The Suleimanji Tariqa (Sufi order) was created based on his teachings.
} 
suitable for other community purposes. The other two communities have outgrown their properties used as centres, but have not been able to find appropriate buildings or solutions to organise their community life. The centre for the Islamic Church (the Dar-as-Salam Mosque in Budapest) - which has meanwhile lost its legal legitimacy, but remains a community - is located in a leased property in Bartók Béla Street. The centre of the MIK can be found in Sáfrány Street. The Turkish community has a large prayer room in the Eighth District (Józsefváros) of Budapest.

Islam requires community participation. Believers try to assemble for daily prayers, especially the prayer at Friday noon (khutba) and the fast of Ramadan. This is why the issue of establishing/constructing a mosque or the extension arises relatively quickly when the community expands, and also demonstrates organisational and community needs. The symbols and principles of Islam are usually reflected in the building itself, e.g. in the case of the separation of sexes, or a minaret which receives a lot of attention. Mosques and Islamic cultural institutions are the objectified targets of current global disputes about Islam. The construction of new mosques, and especially new minarets, divides non-Muslim societies all over the world.

One instance of anti-Islamic protest in Hungary took place in the Eleventh District of Budapest, where the Islamic Church began the construction of a new mosque and Islamic cultural centre. During the protests, local residents cited increasing traffic, the environmental impact, noise and also the increase of a terrorist threat during the protests (CSICSMANN \& VÉKONY 2011). The construction was involved in political disputes, as 2010 was also a year when national elections were held. Construction eventually became impossible, and the local authority revoked the building permission for technical grounds.

Compared with other European cases, the Hungarian case is special in various respects. This is due to some monument camis having survived from the era of the Ottoman occupation. The Öziçeli Hacci Ibrahim mosque, located in Esztergom, is used as a museum, its renovation having recently been completed. Since it is in the vicinity of Esztergom Cathedral, permission to renovate the minaret was refused due to concerns about the "cityscape", and its place is marked with a stub, a unique architectural solution. Occasional prayers are allowed in the mosque. The Malkoch Bey mosque in Siklós and the Yakovali Hassan mosque in Pécs are museums, although both are used by Muslims for religious purposes as well. The building in Pécs is in surprisingly intact condition, and it is unique in Hungary in having a minaret. The mosque in Siklós is primarily used by a handful of Bosniaks, while the mosque in Pécs is the centre of the local Sunni community (which belongs to the MME).

The Suleiman Sultan mosque in Szigetvár Castle also functions as a museum. The building, constructed in the $16^{\text {th }}$ century, is of high cultural history importance and some (especially Turkish) Muslim visitors use it for prayers as well. A historic reconstruction of the mosque is currently in preparation. The issue of rebuilding the minaret is the most sensitive part of the works, due to its symbolic importance. ${ }^{14)}$

\footnotetext{
14) The buildings of the Szigetvár Castle convey a complex message. They do not only commemorate Suleiman the Magnificient, but also a prominent hero in Croatian and Hungarian history, Miklós Zrínyi (Nikola Šubić Zrinski).
} 
Although the Szigetvár Ali Pasha Mosque and the Mosque of Pasha Qasim in the centre of Pécs are ordained Catholic churches, their original architecture is clearly visible as a result of historic renovation.

In Pécs, the Catholic church in Ágoston Square also shows some Ottoman features, as it was once used as a mosque, and the cami of Ferhad Pasha and some attached remains were discovered in Kazinczy Street in the city centre a few years ago in the course of demolition of a building. The remains of Ottoman mosques are also to be found in other Hungarian settlements (Szolnok, Eger). As a representative of the Turkish government, the Turkish Cooperation and Coordination Agency surveyed Ottoman monuments, especially tombs and mosques, in 2012 and 2013, and the preparatory work for restoration of the monuments has begun. After historic restoration, they are expected to request the provision of Muslim religious practice in the restored buildings.

In addition to general religious intolerance and xenophobia, disputes related to the construction of a mosque are - explicitly and implicitly - generated by concerns about alleged Islamic extremism. Is this concern justified? According to experiences so far, it is not, or only very slightly. Immigrant Muslims are typically young men, some of whom have chosen local wives, but they also try to adapt to local customs. The interpretation of Islam as presented by radical preachers who turn up from time to time cannot be followed in Hungary (or it would be very difficult), and therefore they do not stay in these communities. There have been no serious conflicts in Hungary that would indicate the presence of a social basis for radicalism with an Islamic background. In the few such cases, the investigations did not confirm the relevance of such allegations.

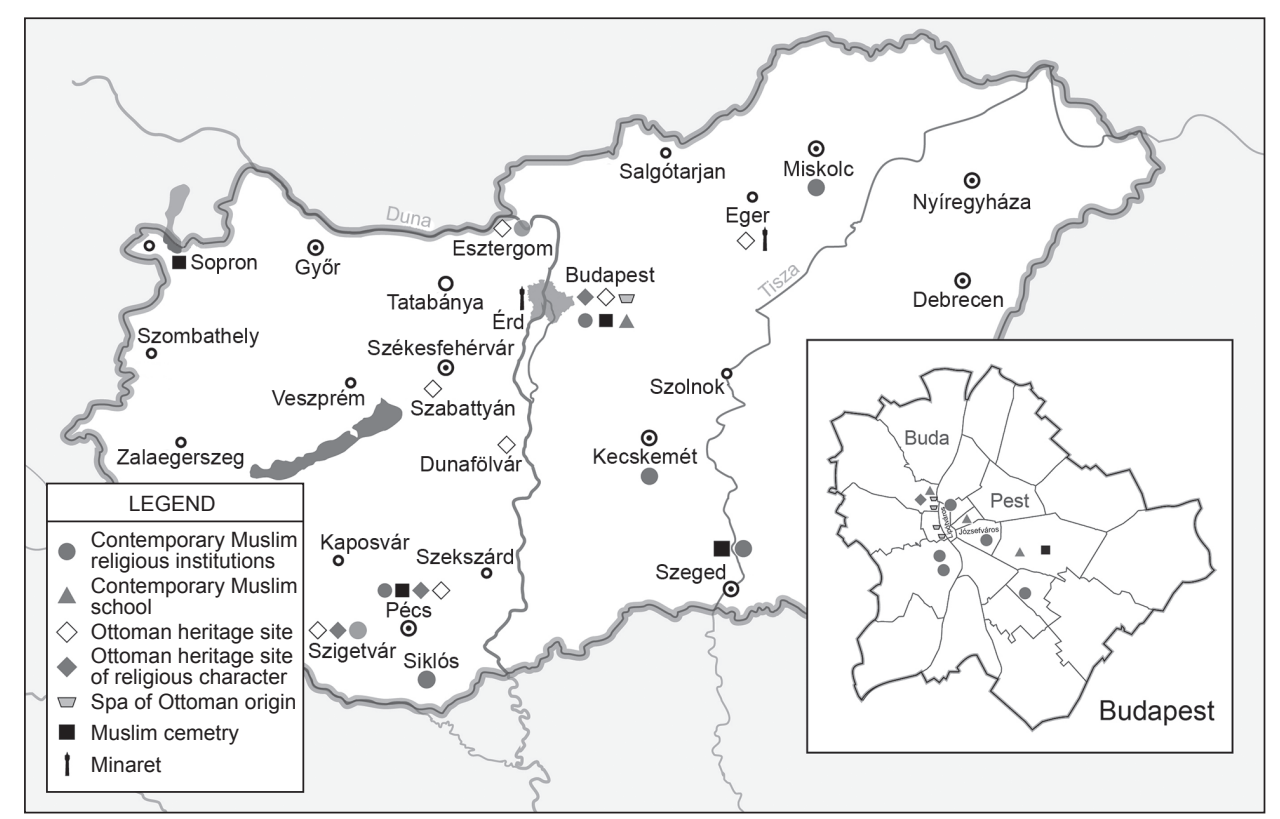

Fig. 4: The most important Islamic sites in Hungary (2014) 


\subsection{Schools, weddings, funerals}

Religious instruction for children (and adults as well) is available in mosques. However, there are two primary schools in Budapest that provide partially religious education for children. The institute in Kavics Street is maintained by the Libyan government, and also offers Arabic language training. The Turkish government also maintains a primary school in Cserkesz Street, where the majority of pupils are Muslims. Gülenist Turks have also established two schools in Budapest. Muslim religious organisations regularly organise religious trainings for children at the weekends, teaching them the Quran and other parts of Islamic knowledge. In addition to this, the $\mathrm{OMH}$ has organised Islamic religious training in a public school in the Eighth District of Budapest.

There are no Muslim higher education institutions in Hungary, although several Hungarian universities offer Islam-related studies for their students. Such programmes are available at the University of Pécs, at Eötvös Loránd University in Budapest, at the Budapest Corvinus University and at the Péter Pázmány Catholic University. Hungarian Muslims pursue their studies at Al-Azhar University in Cairo [Al Kahira] and at the Chateau-Chinon University of France, or in colleges and universities in Turkey.

Hungarian laws do not recognise an Islamic marriage in itself. However, mosques offer preparatory pre-marital courses and there is an opportunity for marriages to be concluded based on sharia law, which may be recognised in certain Muslim countries, but not in Hungary.

The Turkish soldiers who died on the Galician front in the First World War are buried in the Kozma Street Cemetery in Budapest. Muslims in Budapest are usually buried near this place. There is another military cemetery near Sopron, where the Bosniak and Turkish soldiers who fell in the First World War are buried. There are also separate sectors designated for Muslims in the public cemeteries of major Hungarian cities, such as Pécs, Szeged and Debrecen.

\section{Social role and political importance of Hungarian Muslims}

The Hungarian Muslim community has a rather youthful age structure, and the average standard of living of its members is below that of Hungarians. Muslims typically work in the commercial, hospitality and certain technical sectors, and also in healthcare services. Their living conditions are not considered ideal. They perceive negative attitudes from the majority population. All the people answering our questionnaire had had negative experiences, even though typically conflicts are not caused by religious intolerance. But they do not live in apprehension. Their population is concentrated in Budapest, but there are no signs of segregation in the city. There is no Islamophobia, but xenophobia (in the forms of, e.g., anti-Arabic or anti-refugee sentiment) is perceived. 
According to some sources, the degree of secularisation of Hungarian Muslims is somewhere between the situations in Western Europe and in the Balkans. Other reports, however, suggest that the religious practice of Muslims with an Arabic background is significantly different from the practices of Muslims from the Balkans. In our experience, this is also the case with Turks. However, this makes it more difficult to distinguish among individual Muslim groups. Although no such general inquiries have been conducted in Hungary, it can be presumed that they cannot be considered a homogeneous entity, and there are many different groups - from the secular to the strictly orthodox.

Muslim leaders all support social integration efforts and emphasise the importance of loyalty to the state. Two of the three organisations (MME, IE) keep a distance from political parties, while the leader of the MIK emphasises the similarity of his views with those of Christian Democrats. The Islamic Community (MIK) has supported the expression of the Christian spirit and such articles in the constitution, and also explicit moral provisions similar to the teachings of Islam. Yet, in daily politics, the MIK maintains the closest relations with Jobbik, a radical nationalist party. ${ }^{15)}$ They have found their common ground in anti-Semitic sentiment. The articles of the new constitution referring to Christianity were rejected by both the MME and the IE as expressions of religious discrimination.

In issues of foreign policy, they play an active role in maintaining Hungary's relationships with Islamic states in the world. They have typically rejected Hungarian military participation in NATO missions to Iraq and Afghanistan. The foreign policy agenda of MIK and Jobbik are very similar (CSICSMANN 2012).

MIK and MME have joined different moderate European umbrella organisations, but reject the more liberal viewpoints thereof and emphasise a worldwide unity of Islam. The current government's "Eastern Opening" policy of seeking connections with Asia is supported by all Muslim organisations (CSICSMANN \& VÉKONY 2011; PAP 2013c). However, there are some reservations in place with regard to MIK, as it is in contact with such extremist regimes as the one in Sudan.

Several scholars have emphasised that the pro-Islamic approach of Hungarian national radicalism is very unique in Europe (RózSA 2010; CSICSMANN \& VéKONY 2011; PAP \& LADÁNYI 2012, 2013). While the main characteristic of the far right in Western Europe is anti-Islamic sentiment, in Hungary it is anti-Semitic and anti-Roma sentiment. ${ }^{16)}$ In our opinion, this is not exclusively (or not primarily) caused by the fact that there are no significant Islamised masses in Hungary (yet), but due to complex historical and identity-related reasons.

\footnotetext{
15) At the national elections of 6 April 2014, Jobbik received $20.3 \%$ of the votes, which made it the thirdlargest faction in the current Hungarian parliament.

${ }^{16)}$ Indeed, the acceptance of Jobbik among Eurosceptic, radical nationalist European political groups is quite dubious due to this pro-Islamic approach.
} 


\section{The role of Islam in Hungarian "national mythology"}

Hungarians are strongly divided in cultural and political matters, and some social groups (especially among the intelligentsia) are sensitive to certain questions that affect national identity. These groups are highly concerned about early Hungarian history, and the fates and historic roles of peoples that joined the Hungarians and assimilated with them.

As presented above, certain peoples following the Muslim religion have played significant roles in the history of Hungary and contributed to enriching the "national mythology". The main elements of these national myths affect the majority of the population, but play an even larger role in the thinking of certain political subcultures (nationalist groups, radical nationalists).

The centrepiece of this national mythology is the historical fact that Hungarians are originally from the East, and migrated to Europe from Asia, preserving several original and additional cultural impacts from the Turkic and Iranian peoples of the steppes. There are many possible interpretations to this, but some think that the contemporary Islam Turkic peoples should be considered "relatives" of the Hungarian people.

This paper has shown that some of the eastern peoples (especially of Turkic origin) who assimilated completely into the Hungarian race certainly did follow the Muslim faith, while some others probably did so. A permissive view might mean that a significant part of the predecessors of Hungarians in the Middle Ages could have been following Islam.

One basic question of national politics in the $16^{\text {th }}$ and $17^{\text {th }}$ centuries was whether the unity of a country torn apart would be restored under the Habsburg rule by driving out the Ottomans with help from Western/Christian forces, or, through loose dependence with the Ottomans, by breaking the rule of the Habsburgs. The question has been answered, but the disputes continue to this day. The freedom fight of Imre Thököly took place simultaneously with the liberation wars against the Turks, which is why as many Hungarians fought on the Muslim side, against the Habsburgs, as among the Christian troops against the Turks. The Hungarian Protestants in the liberated territories started to enjoy the years of Muslim rule, which gave them the opportunity to practise their religion freely. They later played a major role in national struggles. Some time later, under the leadership of Ferenc Rákóczi, almost a decade of fighting began against the rule of the Habsburgs. After losing the war, the emigrants settled in Turkey, near Istanbul.

The perception of Turkish rule in Hungary is one of the topics about which no national consensus exists, and there are various - Protestant and Catholic, rebel and loyalist, national and pro-European - interpretations. Some consider it a major derailment of national development, others (as a minority opinion) consider it a lost opportunity for the nation to attain liberty and control its own fate.

Perhaps the most mobilising and significant chapter of Hungarian national tradition is related to the Hungarian Revolution and War of Independence of 1848-49. In 1849 , several leaders and soldiers (including high-ranking officers) fled to the Ottoman Empire, and not only were they granted asylum, but many of them also soon joined the Turkish army and converted to Islam. 
In the last third of the $19^{\text {th }}$ century friendship with the Turks was very popular. What came to be known as the "Ugric-Turkish dispute" on the origins of the Hungarian language was not only a matter of science, but also a dispute on identity and has not yet completely been settled.

During the Balkan Wars, Turkish troops fled to Hungarian territories and were granted asylum. A few years later, in the trenches of the First World War, in some places Hungarian troops fought together with Turkish and Bosnian Muslims. In the Dardanelles Campaign the Turkish troops were supported by Hungarian officers. The memory of this alliance is still alive today.

Due to these events and the particular interpretations and sentiments related to them, some groups of Hungarians feel a rare type of understanding toward Eastern peoples, especially Turks, and the Muslim religion. Indeed, by far the most popular Hungarian novel is Eclipse of the Crescent Moon [Egri Csillagok], a historical novel on the siege of Eger in 1552 and the events preceding it, bearig evidence of the heightened interest in the events of the era. Another particular phenomenon is the park of Turkish-Hungarian friendship in Szigetvár, established 20 years ago in 1994 on the $500^{\text {th }}$ anniversary of the birth of Suleiman I (who died during the siege of Szigetvár), in order to commemorate peace and friendship.

\section{Conclusion}

Hungarians were already in contact with Islam before their conquest of the Carpathian Basin, somewhere around the Northern coast of the Black Sea, during their time in the Khazar Empire, and Muslims groups have also joined Hungarians in significant numbers. As a strong mainstay of principal and royal power, the Muslim community comprising different eastern peoples could resist the assimilation efforts of the Christian Church (with the explicit or implied support of the monarch). With new waves of eastern immigrants, it was even able to renew itself. The several different names applied to these peoples (Khwarezmian, Ishmaelites, Saracens and "Böszörmény" people) reflect different ethnic backgrounds and/or origins. They have held important offices of financial administration, in military organisations and the royal guard. They did not settle in one bloc, but on royal estates, based on their positions. Then at the end of the age of the Árpád dynasty, they disappeared from the sources, and had completely assimilated by the $14^{\text {th }}$ century.

In the Ottoman era (1541-1699) the Islamised population from the Balkans settled in the central third of the country, mostly consisting of Southern Slavs, Vlachs and Albanians, but they could only establish temporary structures. The number of Hungarian converts was few, only some cases being known, especially in the $16^{\text {th }}$ century. The number of actual Turks is likely to have been very low. Bosnian relations were the most decisive. They primarily appeared in castles as military personnel and in towns as elements in the military, administrative and religious organisations to provide protection in this border area of the Empire. During the Turkish occupation, the infrastructure of the Ottoman urban lifestyle, mosques, schools and baths were established. Mus- 
lims only populated settlements in defensible areas (Transdanubia and the mountain ranges in the north), and few places were fortified adequately in the Great Hungarian Plain for Muslims to move into. The region joined the intellectual bloodstream of the Islamic world as well. During the liberation wars of the late $17^{\text {th }}$ century, Muslims fled the country and the few thousands that wished to stay converted to Christianity and assimilated into the Hungarian and Croatian ethnic groups. Mosques and tombs were partially transformed into chapels and churches. Although without justification, the era of the Ottoman conquest entered Hungarian history books as a rather negative period. Following failed struggles for independence in the $18^{\text {th }}$ and $19^{\text {th }}$ centuries, outlawed, exiled Hungarians typically fled to Turkish lands and received asylum there. This gradually changed the relationship with Ottomans and Turks to controversial and then to partially positive.

After the occupation of Bosnia-Hercegovina in 1878, new and rather small Muslim groups (Bosniaks and Turks) settled in Hungary, where laws regarding their religious practice gradually became favourable to them. Bosniaks appeared in the army, and also in retail trades. Policies affecting other Southern Slavic communities also supported the emancipation of Muslims, and as a result the legal status of the Muslim community was settled in 1916. The (mostly) Bosnian Muslims participating in military action in Western Hungary after the First World War earned serious legitimacy and laid the cornerstones of a favourable relationship with Hungarian centre-right, revisionist, and also far-right political groups. Although their numbers decreased in Hungary, they successfully established a religious organisation in Budapest in 1931. When the Communists took power after the Second World War, they terminated Muslim community activities, and many Turks and Bosniaks left the country.

In the very last hours of the Communist era, students from Arabic countries and Hungarian Muslims began to establish religious organisations. After the transition to democracy, the reorganisation of legal frameworks and greater freedom in travelling enabled an increase of migration, initiating a process that led to the current situation. Muslims settled in Hungary from further-off areas of the Islamic world, particularly including Arabic countries, but also Turkey, Central and Southern Asia. As a result of military conflicts, people also arrived from Kosovo and (in smaller numbers) from Bosnia. However, compared to earlier periods, the number of Muslims from the Balkans is much lower than those arriving from Arabic and other Asian regions. The number of Hungarian converts is also rather significant. The Muslim community is greatly divided, and they cannot integrate the majority of the followers of Islam living in Hungary. The Muslim religious organisation with the longest history undertakes to represent continuity with the religious entity that existed in the interwar period, and participates actively in politics. Just like its predecessor in the 1930s, it is known to cooperate with conservative, and sometimes with far-right political groups.

Due to their specific historical experience, Hungarians have some unique characteristics related to Islam. These contribute to radical nationalists not building upon Anti-Muslim sentiment, but having other issues on their agenda (anti-Semitism and anti-Roma racism). Moreover, there is no widespread Islamophobia in Hungary, and there are open and friendly relationships with Muslim peoples living in the region. 


\section{References}

AdORJÁn I. (1988), Muzulmánok a magyarok közt a kezdetektől az Árpád-kor végéig [Muslims among the Hungarians from the first encounters to the end of the Árpád era]. Székesfehérvár, Fejér Megyei Pedagógiai Intézet.

Ágoston G. (1993), Muszlim hitélet és múvelődés a Dunántúlon a 16.-17. században. - Tanulmányok a török hódoltság és a felszabadító háborúk történetéből [Muslim religious life and education in Transdanubia in the $16^{\text {th }}$ and $17^{\text {th }}$ centuries. - Papers about the history of the Ottoman conquest and the liberation wars]. In: Baranya Megyei Levéltár, pp. 282-287.

Ágoston G. (2005), Coexisting cultures in Ottoman Hungary, Jewish religious and cultural life in Ottoman Hungary, Muslim culture in an occupied land, Dervishes and their orders, Muslim libraries in Hungary. A Concise History of Hungary. Budapest, Corvina and Osiris.

al-Gharnati, Abu-Hamid (1985), Abu-Hamid al-Garnáti utazása Kelet-és Közép-Európában 1131-1153 [The travels of Abu-Hamid al-Garnáti in Eastern and Central Europe in 1131-1153]. Budapest, Gondolat.

Anwar M. (2001), Az iszlám [Islam]. In: Kultúra és Közösség, IV-2002, I, 92.

B ARTHA A. (1968), A IX-X. századi magyar társadalom [Hungarian society in the $9^{\text {th }}$ and $10^{\text {th }}$ centuries]. Budapest, Akadémiai Kiadó.

B ARtha A. (1988), A magyar nép őstörténete [Ancient history of the Hungarians]. Budapest, Akadémiai Kiadó.

BOLEK Z. (2002), A magyar iszlám története [History of Islam in Hungary]. - http://www.magyariszlam.hu (last access 21.10.2014)

CsÁsZÁr Zs., Pete J. (2008), A Kárpát-Balkán térség és az iszlám kapcsolatának térbeli és történeti aspektusai [Spatial and historical aspects of the relations between the Carpatho-Balkan area and Islam]. In: Szabó V., Orosz Z., Nagy R., FazeKas I. (eds.), IV. Magyar Földrajzi Konferencia Debrecen: Debreceni Egyetem,pp. 444-450. Debrecen, Debreceni Egyetem.

Csicsmann L. (2011), A magyarországi muszlim kisebbségek társadalmi integrációjának kihívásai az európai tapasztalatok tükrében. [Challenges of social integration of the Hungarian Muslim minorities in the light of European experiences]. Final Report TAMOP74.2.1/ B709/1/KMR7201070005.

Csicsmann L., Vékony D. (2011), Muslims in Hungary: A Bridge between East and West? In: Bures J. (ed.), Muslims in Visegrad, pp. 53-67. Prague, Institute of International Relations Prague.

DÁvid F., OláH P. (2012), Törökország és a kaukázusi régió szerepe a '40-es évek magyar külpolitikájában. [Turkey and the Caucasus region in the foreign policy of Hungary in the 1940's]. In: Szakmai Szemle, pp. 193-194.

Duman S. (2010), Ismet Inönü Dönemi Türkiye-Macaristan ilişkileri [Turkish-Hungarian relations in the period of Ismet Inonu] (= Uluslararası Türk Macar İlişkileri Sempozyumu).

Evliya ÇElebi (1908), Evliya Çelebi török világutazó magyarországi utazásai. (trans. Imre Karácsony) [The travels of Evliya Çelebi, the Turkish world traveller in Hungary]. Budapest, MTA.

FARKAS I. (2007), A magyar turanizmus török kapcsolatai [Turkish connections of Hungarian turanism]. In: Valóság, 6, pp. 57-73.

Fazekas Cs. (1996), Kisegyházak és szektakérdés a Horthy-korszakban [Free Churches and the sect issue in the Horthy era]. Budapest, TEDISZ - SzPA.

Ferenci D.E. (2010), Magyarok és az iszlám [Hungarians and Islam]. - http://www.academia. $e d u / 796537 /$ (last access 21.10.2014). İstanbul, Demirpress. 
Fodor I. (1988), Kazárok és kabarok [Khazars and Kabars]. In: Szombathy V., LÁszló Gy. (eds.), Magyarrá lett keleti népek, pp. 61-105. Budapest, Panoráma Kiadó.

Fodor P. (1991), Magyarország és a török hódítás [Hungary and the Ottoman conquest]. Budapest, Argumentum.

Fogarassy L. (1972), A nyugat-magyarországi kérdés katonai története [Military history of the Western Hungary question]. In: Soproni Szemle, 2, pp. 20-30.

GyörfFY Gy. (1990), A magyarság keleti elemei [Eastern elements of the Hungarians]. Budapest, Gondolat Kiadó.

GYUROK J. (1994), Jugoszláviai menekültek Magyarországon [Yugoslavian refugees in Hungary]. In: Regio - Kisebbség, politika, társadalom, 5, 4, pp. 50-65.

HegYi K. (1995), Török berendezkedés Magyarországon [The Ottoman arrangement in Hungary] (= História Könyvtár, Monográfiák, 7). Budapest, História.

KARÁCSONYI J. (1913), Kik voltak s mikor jöttek hazánkba a böszörmények vagy izmaeliták? [Who, where and when did the Busurmans or Ismaelites arrive to Hungary?] (= ÉTK, XXIII/7). Budapest, Magyar Tudományos Akadémia.

KatonA-Kiss A. (2010), A „sirmioni hunok” Egy muszlim katonai kötelék a XII. századi magyar katonai erőkben [The „Sirmion Huns”. A Muslim military unit in the $12^{\text {th }}$ century Hungarian army]. In: Almási T., Révész É., Szabados Gy. (eds.), „Fons, skepsis, lex” Ünnepi tanulmányok a 70 esztendős Makk Ferenc tiszteletére, pp. 159-171. Szeged, SZTE Történeti Segédtudományok Tanszék, Szegedi Középkorász Múhely.

Kiss E. (2002), Muszlimok Budapesten [Muslims in Budapest]. In: Kiss E., Anwar A., Csiszár A. (eds.), Az iszlám Magyarországon és a Közel-Keleten. Budapest, MTA PTI Etnoregionális Kutatóközpont, Munkafüzetek.

Kitanics M. (2006), A Magyarországra irányuló horvát migráció a 15-18. Században [Croat migration towards Hungary from the $15^{\text {th }}$ to the $18^{\text {th }}$ centuries]. In: PAP N. (ed.), A Balatontól az Adriáig, pp. 59-73. Pécs, Lomart Kiadó.

KRISTó Gy. (2003), Nem magyar népek a középkori Magyarországon [Non-Hungarians in medieval Hungary]. Budapest, Lucidus Kiadó.

LÉDERER Gy. (1988), A magyarországi iszlám újabb kori történetéhez I. [To the modern history of Hungarian Islam I]. In: Keletkutatás, pp. 29-49.

LÉDERER Gy. (1989), A magyarországi iszlám újabb kori történetéhez II. [To the modern history of Hungarian Islam II]. In: Keletkutatás, pp. 53-72.

MAKKAI B. (2013), Bosznia-Hercegovina mint magyar kivándorlási, avagy expanziós célterület [Bosnia-Hercegovina as an area of Hungarian emigration or expansion], pp. 135-146. - http://www.prominoritate.hu/folyoiratok/2013/ProMino-1301-08-Makkai.pdf (last access 21.10.2014).

MANDERSPRACH V. (1926), Élményeim a nyugat-magyarországi szabadságharcról [Memories of the Western Hungarian freedom war]. In: Magyarság folyóirat, 1-5, pp. 6-38.

Mihálffy B. (1991), A Magyar Iszlám Közösség [The Hungarian Muslim community]. In: GeszTElyi T. (ed.), Egyházak és vallások a mai Magyarországon, pp. 182-187. Budapest, Akadémiai Kiadó.

Nielsen J. (ed.) (2013), Yearbook of Muslims in Europe. Amsterdam, Brill.

OLÁH P. (2012), A török és a magyar turanizmus kapcsolata a 20. század első felében [Relations of Turkish and Hungarian turanism in the first half of the $20^{\text {th }}$ century]. In: Keletkutatás, pp. 67-86.

OrtutAy Gy. (ed.) (1977), Magyar néprajzi lexikon, I. kötet, ,bosnyákok” címszó Főszerk. Ortutay Gyula [Hungarian Ethnographic Lexicon vol. I, Bosniaks]. Budapest, Akadémiai Kiadó. 
Paládi-KovÁcs A. (ed.) (2000), Magyar néprajz VIII. Társadalom [Hungarian Ethnographic VIII Society], p. 1152. Budapest, Akadémiai Kiadó.

Palóczi-Horváth A. (1988), Besenyők, úzok, kunok [Pechenegs, Oghuz Turks, Cumans]. In: Szombathy V., László Gy. (eds.), Magyarrá lett keleti népek, pp. 106-163. Budapest, Panoráma.

PAP N. (2011), Hungary. In: Nielsen J. (ed.), Yearbook of Muslims in Europe, pp. 269-276. Amsterdam, Brill.

PAP N. (2013a), A muszlim közösségek szerveződésének sajátosságai Kelet-Közép Európában [Organisational characteristics of Muslim societies in East-Central Europe]. In: Civil Szemle, 2, pp. 49-65.

PAP N. (2013b), A pécsi szunnita muszlim közösség [The Sunni Muslim community of Pécs]. In: Kisebbségkutatás, 2, pp. 120-133.

PAP N. (2013c), Hungary, the Balkans and the Mediterranean. Pécs, Publikon.

PAP N. (ed.) (2014), Szulejmán szultán emlékezete Szigetváron [The memories of Sultan Suleyman the Magnificient in Szigetvár] (= Mediterrán és Balkán Fórum, VIII). Pécs, University of Pécs.

Pap N., Ladányi É. (2012), Hungary. In: Nielsen J. (ed.), Yearbook of Muslims in Europe, pp. 281-288, 319-326. Amsterdam, Brill.

Pap N., Ladányi É. (2013), Hungary. In: Nielsen J. (ed.) Yearbook of Muslims in Europe, pp. 319-326. Amsterdam, Brill.

PAP N., NAGy J.T., VÉGH A., LÉPHAFt Á. (2013), A magyarországi muszlim migránsok az információs társadalomban [Hungarian Muslim migrants in the information society]. In: Információs Társadalom, 3-4, pp. 59-78.

RónA-TAs A. (1997), A honfoglaló magyar nép [The landtaking Hungarians]. Budapest, Balassi Kiadó.

Rózsa E. (2010), Muszlim kisebbségek Közép-Európában, avagy Közép-Európa különlegessége [Muslim minorities in Central Europe or the particularity of Central Europe]. In: Rostoványi Zs. (ed.), Az iszlám Európában, pp. 405-446. Budapest, Aula Kiadó - Budapesti Corvinus Egyetem.

ŠAROŠAC Đ. (1991), Bosanski Hrvati u okolici Pečuha (ekonomska osnovica seoskog života) [The Bosnian Croats in the surroundings of Pécs (economic characteristics of rural life)]. In: Biblioteka Dunav, pp. 13-17. Budapest, Tankönyvkiadó.

SoKCSEvits D. (2011), Horvátország a 7. századtól napjainkig [Croatia from the $7^{\text {th }}$ century until today]. In: Mundus Novus könyvek, Budapest, pp. 743-751.

SudÁr B. (2003), Kulturális létesítmények a török hódoltságban II. Iskolák, fürdők [Cultural facilities in Ottoman Hungary II, schools, baths] (= História, 4).

SudÁr B. (2008), Bektaşi Monasteries in Ottoman Hungary $\left(16^{\text {th }}-17^{\text {th }}\right.$ centuries) In: Acta Orientalia Academiae Scientiarium Hungaricae 61, 1-2, pp. 227-248.

Sulok Z. (2010), Muslim minority in Hungary. Paper for the Warsaw Symposium for the Muslim minorities in Eastern and Central Europe $8-10^{\text {th }}$ December 2010, Budapest, pp. 76-85.

TARJÁn M.T. (2014), 1921. augusztus 28. Kirobban a nyugat-magyarországi felkelés [ $28^{\text {th }}$ August, 1921. The Western Hungarian revolution broke out]. - http://www.rubicon.hu/ magyar/oldalak/1921_augusztus_28_kirobban_a_nyugat_magyarorszagi_felkeles/(last access 21.10.2014).

UdVARVÖLGYI Zs. (1998), A magyar iszlám vallásszociológiája [Sociology of religion of the Hungarian Islam]. Budapest, ELTE Szociológiai Intézet.

UdvarVÖLGYi Zs. (2010), A Magyar Iszlám Közösség megalapítása (1988) [Establishment of the Hungarian Islam Community]. In: Egyháztörténeti Szemle, 11, 4, pp. 133-147. 
VÉGH A. (2004), A horvát anyanyelvi oktatás 50 éve Pécsett, Vonzáskörzeti vizsgálatok Pécs városának néhány horvát anyanyelvú intézményében [50 years of mother tongue-based Croatian education in Pécs. Enrollment area researches in some Croat language institutions of Pécs]. In: ReménYi P. (ed.), Az integrálódó Európa politikai földrajza: III. Magyar Politikai Földrajzi Konferencia: Pécs, 2002. november 7-8, pp. 296-301. Pécs, PTE TTK Földrajzi Intézet. 